\title{
Accumulation of noncrystalline cellulose in Physarum microplasmodia
}

\author{
Kyoko Ogawa $\cdot$ Hisae Maki $\cdot$ Mamiko Sato $\cdot$ \\ Hiroshi Ashihara • Takako S. Kaneko
}

Received: 16 November 2012 / Accepted: 12 February 2013 / Published online: 2 March 2013

(C) The Author(s) 2013. This article is published with open access at Springerlink.com

\begin{abstract}
Physarum plasmodium lives as a slimy mass of protoplast in the dark fragments into small multinucleated microplasmodia (mPL) in a liquid medium. When $\mathrm{mPL}$ are exposed to several unfavorable environments, they transform into "spherules" with a cell wall. Using a synchronous spherule-induction system for mPL, we examined the effect of 2,6-dichlorobenzonitrile on the synthesis of cellulose in $\mathrm{mPL}$, by observing $\mathrm{mPL}$ under a fluorescence microscope, and isolated cellulose from mPL to identify them morphologically under scanning electron microscopy. Moreover, we examined in vivo labeling to determine when cellulose synthesis is activated in step 2 . We found that the nourishment medium in step 2 was essential for mPL prior to spherulation and that the conversion starts at $48 \mathrm{~h}$ in step 2 of our system. From the experiments using Updegraff reagent for the sedimentation of cellulose in the cell wall fraction from $\mathrm{mPL}$, we propose that cellulose produced in $\mathrm{mPL}$ is likely noncrystalline cellulose. We conclude that $\mathrm{mPL}$ of multinucleated protoplasts without the cell wall structure synthesize cellulose under constitutive condition and accumulate abundantly noncrystalline cellulose, in preparation for unfavorable environments that may occur
\end{abstract}

Handling Editor: Liwen Jiang

K. Ogawa $(\bowtie) \cdot$ H. Maki $\cdot$ T. S. Kaneko

Department of Chemical and Biological Sciences, Faculty

of Science, Japan Women's University, Mejirodai,

Bunkyo-ku, Tokyo 112-8681, Japan

e-mail: ogawa-k@fc.jwu.ac.jp

M. Sato

Laboratory of Electron Microscope, Japan Women's University,

Bunkyo-ku, Tokyo 112-8681, Japan

H. Ashihara

Department of Biological Sciences, Graduate School

of Humanities and Sciences, Ochanomizu University,

Bunkyo-ku, Tokyo 112-8610, Japan in the future in which mPL must initiate the program to form the cell wall of spherules.

Keywords Cellulose-binding domain (CBD) .

2,6-Dichlorobenzonitrile (DCB) · Physarum polycephalum . Spherulation · Updegraff reagent

\section{Introduction}

A plasmodium of the myxomycete, also treated as protozoan Physarum polycephalum, lives as a slimy mass of protoplast in the dark and fragments into small multinucleated microplasmodia (mPL) in a liquid medium. mPL respond to an unfavorable environment by differentiating into "spherules" without undergoing meiosis. The transformation of mPL into spherules with a cell wall is induced by transferring $\mathrm{mPL}$ to a starvation medium (Guttes and Guttes 1963). Since Guttes and Guttes (1963), the mechanism of the spherulation by mPL has never been studied. In order to elucidate the mechanism on the spherulation, in our previous study (Ogawa et al. 2010), we established a synchronous spherule-induction system for $\mathrm{mPL}$ consisting of three steps as follows: $\mathrm{mPL}$ are subcultured in the basal medium containing $1 \%$ sucrose and $1 \%$ soytone peptone $(1 \%$ medium) for $84 \mathrm{~h}$ (step 1). After subculturing, mPL are transferred to the basal medium containing the doubled concentrations of sucrose and soytone peptone ( $2 \%$ medium) for $72 \mathrm{~h}$ as the preculture (step 2). Spherules are induced by transferring mPL to the starvation medium and by incubating for $96 \mathrm{~h}$ in the dark (step 3). Using this synchronous spherule-induction system, we determined that the major component of the cell wall of spherules is cellulose. Taking the effect of 2,6-dichlorobenzonitrile (DCB) on the synthesis of cellulose in spherules into consideration, we elucidated that it is in the nourishment medium in step 2 prior to the dark-starvation treatment that $\mathrm{mPL}$ of 
multinucleated protoplasts without the cell wall synthesize cellulose fibrils de novo (Ogawa et al. 2010). However, it remains uncertain that mPL of multinucleated protoplasts synthesize cellulose without the cell wall and that mPL can, however, crawl around to look for food with cellulose, the major component of plant cell wall which immobilizes the cell. Furthermore, there is little possibility that mPL contain hemicellulose and pectin, etc., because such cell wall components build stiff cellulose in plant cell wall.

In this study, to confirm the accumulation of the cellulose fibrils of the cell wall in Physarum mPL, we examined the effect of DCB on mPL by observing mPL under a fluorescence microscope equipped with a confocal laser scanning head system and isolated cellulose from mPL to identify them morphologically by scanning electron microscopy (SEM). Moreover, we conducted in vivo labeling experiments using D-[U- $\left.{ }^{14} \mathrm{C}\right]$ glucose to determine when cellulose synthesis is activated within a period of $72 \mathrm{~h}$ in step 2 and to measure the quantitative changes of $\mathrm{mPL}$, by measuring the amount of D- $\left[\mathrm{U}_{-}{ }^{14} \mathrm{C}\right]$ glucose incorporated into the cell wall fraction from $\mathrm{mPL}$.

These experiments were performed using acetic nitric reagent (Updegraff reagent) for the sedimentation of cellulose in the cell wall fraction, to detect cellulose fibrils. Updegraff (1969) developed the method of determining cellulose content in biological materials; after treatment with Updegraff reagent, the remaining cellulose was hydrolyzed in $67 \%$ sulfuric acid, and then glucose content was determined by the anthrone method (Scott and Melvin 1953). Since his report, Updegraff reagent has been used in many studies (Arioli et al. 1998; Kimura and Itoh 1998; Peng et al. 2001; Lai-Kee-Him et al. 2002; Takahashi et al. 2009; Cifuentes et al. 2010). Arioli et al. (1998) used Updegraff reagent for quantitative determination of cellulose in the rsw1 mutant of Arabidopsis with impaired cellulose synthesis. Kimura and Itoh (1998) showed that a specialized structure, the tunic cord, is composed of bundled microfibrils of cellulose I with high crystallinity in Polyandrocarpa misakiensis, as determined using the reagent for examining sedimentary cellulose by transmission electron microscopy and SEM. Lai-Kee-Him et al. (2002) analyzed the differences between in vitro synthesized cellulose and in vivo cellulose microfibrils in terms of their crystallinity and sensitivity toward the reagent in Rubus fruticosus (blackberry). Moreover, Peng and co-workers $(2001,2002)$ used Updegraff reagent to determine the process of cellulose synthesis by in vivo labeling of developing cotton fibers. They found that glucan remains insoluble after treatment with the reagent and could be defined as crystalline cellulose and that 4-linked glucan is not resistant to the reagent and could be defined as noncrystalline cellulose. Recently, Takahashi et al. (2009) have quantified crystalline cellulose using the method of Updegraff after hydrolysis of noncellulosic polysaccharides with the reagent in Arabidopsis. They reported that cellulose treated with Updegraff reagent is crystalline. Cifuentes et al. (2010) described that the structure resistant to Updegraff reagent, which has been shown to hydrolyze noncellulosic compounds, corresponds to straight cellulose microfibrils. In this study, we confirmed the existence of cellulose fibrils by observing the deposition of cellulose on MPL in step 2 using Updegraff reagent. Furthermore, we supposed the accumulation of noncrystalline cellulose in the cell wall fraction from Physarum mPL, taking their sensitivity toward the reagent into consideration.

\section{Materials and methods}

\section{Culture conditions}

mPL of the $P$. polycephalum $N g-1$ strain were used in all experiments in this study. The spherule-induction system consisted of three steps as follows. As described previously (Ogawa et al. 2010), mPL were subcultured in the basal medium containing $1 \%$ sucrose and $1 \%$ soytone peptone (1\% medium) with shaking on a reciprocal shaker at $130 \mathrm{rpm}$ every $84 \mathrm{~h}$ at $25^{\circ} \mathrm{C}$ (step 1 ). mPL were then transferred to the basal medium containing the doubled concentrations of sucrose and soytone peptone ( $2 \%$ medium) and incubated for $72 \mathrm{~h}$ as the preculture (step 2). Spherule induction was performed by transferring $\mathrm{mPL}$ to the starvation medium, and the cultures were shaken on a reciprocal shaker at $130 \mathrm{rpm}$ for $96 \mathrm{~h}$ in the dark (step 3). These steps were carried out to investigate the inhibitory effect of DCB on cellulose synthesis in the presence or absence of $100 \mu \mathrm{M}$ DCB (Aldrich).

$\mathrm{mPL}$ were harvested by centrifugation at $3,000 \times \mathrm{g}$ for $2 \mathrm{~min}$ at $4{ }^{\circ} \mathrm{C}$. The resulting pellet was washed several times with distilled water and weighed to determine its fresh weight. It was dried at $80{ }^{\circ} \mathrm{C}$ for $2 \mathrm{~h}$ and weighed to determine its dry weight.

\section{Immunofluorescence staining}

An aliquot of the mPL was fixed with $3.7 \%(v / v)$ formaldehyde for $1 \mathrm{~h}$. The cells were then permeabilized with $0.5 \%$ $(v / v)$ Triton X-100 in $50 \mathrm{mM}$ PIPES buffer ( $\mathrm{pH}$ 6.8) with $1 \mathrm{mM} \mathrm{MgCl}_{2}, 5 \mathrm{mM}$ EGTA, and $1 \%(v / v)$ glycerol for $20 \mathrm{~min}$. Prior to immunostaining, the cells were treated with $1 \%(w / v)$ BSA, $0.1 \mathrm{M}$ glycine, and $0.05 \%(v / v)$ Triton X-100 in phosphate-buffered saline (PBS, which is composed of $20 \mathrm{mM} \mathrm{Na} 2 \mathrm{HPO}_{4}-\mathrm{NaH}_{2} \mathrm{PO}_{4}$ (pH 7.0) containing $150 \mathrm{mM}$ $\mathrm{NaCl}$ ), for $20 \mathrm{~min}$. For immunostaining, the cells were treated with the cellulose-binding domain (CBD; recombinant 17$\mathrm{KDa}$ fragment of the cellulase complex) from Clostridium 
cellulovorans (Sigma-Aldrich), washed with PBS, and then incubated for $1 \mathrm{~h}$ with a primary monoclonal anti-CBD antibody produced in a mouse (Sigma-Aldrich) diluted 20-fold in PBS. After washing with PBS, the cells were incubated for $1 \mathrm{~h}$ in a secondary goat anti-mouse IgG antibody conjugated to Alexa Fluor 568 (Molecular Probes, Invitrogen) diluted 20fold in PBS. The cells were washed with PBS and then mounted in an antifading agent (Fluor Guard, Bio-Rad). All procedures were performed at room temperature. Subsequently, the cells were observed under a fluorescence microscope (Leica TCS NT, Leica Microsystems, Mannheim, Germany) equipped with a confocal laser scanning head.

Isolation of native cellulose microfibrils

Preparation of cell wall fraction The cell wall fraction was prepared as follows (Ogawa et al. 2010). After $72 \mathrm{~h}$ in step 2 for mPL preculture and after $96 \mathrm{~h}$ in step 3 for spherule induction, spherules were harvested by centrifugation. The obtained spherules were layered on $40 \mathrm{ml}$ of a solution consisting of $20 \mathrm{ml}$ of $20 \mathrm{mM}$ Tris- $\mathrm{HCl}$ solution ( $\mathrm{pH}$ 7.2) containing $8 \%(w / v)$ sucrose and $20 \mathrm{ml}$ of that containing $35 \%(w / v)$ sucrose and centrifuged at $1,500 \times g$ for $10 \mathrm{~min}$ to remove the slimy fraction. The obtained $\mathrm{mPL}$ were homogenized in $20 \mathrm{mM}$ Tris- $\mathrm{HCl}(\mathrm{pH} 7.2)$ containing $0.4 \mathrm{M}$ sucrose. The resulting homogenates were centrifuged at $1,500 \times \mathrm{g}$ for $10 \mathrm{~min}$. The obtained pellet was resuspended and centrifuged two more times in increasing concentrations $(0.6$ to $1.0 \mathrm{M})$ of sucrose solutions at $2,000 \times \mathrm{g}$ for $10 \mathrm{~min}$ (Crasnier and Giordani 1985). The pellet was washed once in $20 \mathrm{mM}$ Tris- $\mathrm{HCl}$ (pH 7.2) and three times with distilled water. Here, the pellet is called the cell wall fraction.

Preparation for SEM of $m P L$ and spherules For SEM of $\mathrm{mPL}, \mathrm{mPL}$ cultured for $72 \mathrm{~h}$ in step 2 were directly treated with $1 \mathrm{~N} \mathrm{NaOH}$ overnight at room temperature, centrifuged at 2,000 $\times \mathrm{g}$ for $10 \mathrm{~min}$, and washed in water at neutral $\mathrm{pH}$. Then, the obtained pellet was treated with $0.3 \%(w / v)$ $\mathrm{NaClO}_{2}$ in $50 \mathrm{mM}$ sodium acetate buffer (pH 5.0) for $2 \mathrm{~h}$ at $80{ }^{\circ} \mathrm{C}$ and then washed in water at neutral $\mathrm{pH}$. The cell wall fraction from the spherules cultured for $96 \mathrm{~h}$ in step 3 was treated with $1 \mathrm{~N} \mathrm{NaOH}$ and then with $0.3 \%(w / v)$ $\mathrm{NaClO}_{2}$. Each of the pellets was observed by SEM as described in the section of "Scanning electron microscopy."

\section{Enzyme digestion}

mPL were digested with $1.5 \%(w / v)$ cellulase (Trichoderma viride; Cellulase Onozuka RS, Yakult) in $50 \mathrm{mM}$ sodium acetate buffer $\left(\mathrm{pH} \mathrm{5.0)}\right.$ ) for $12 \mathrm{~h}$ at $30^{\circ} \mathrm{C}$. They were further digested with $1.6 \%(w / v)$ laminarinase (Trichoderma $\mathrm{sp}$.; Sigma-Aldrich) in $50 \mathrm{mM}$ sodium acetate buffer ( $\mathrm{pH} 5.0$ ) for $12 \mathrm{~h}$ at $37^{\circ} \mathrm{C}$.
Scanning electron microscopy

As described previously (Ogawa et al. 2010), mPL and spherules were prefixed with $1 \%(v / v)$ glutaraldehyde (GA) overnight at $4{ }^{\circ} \mathrm{C}$, washed with distilled water, and then postfixed with $2 \%(v / v)$ osmium tetroxide $\left(\mathrm{OsO}_{4}\right)$ for $2 \mathrm{~h}$ at $4{ }^{\circ} \mathrm{C}$. After washing for three times with distilled water, they were dehydrated with a graded ethanol series and dried using a critical point drying apparatus (HCP-2, Hitachi, Hitachi, Japan). The dried specimens were sputter coated with Pt-Pd using an ion coater (E-1030, Hitachi, Hitachi, Japan) and observed using S-800 (Hitachi, Hitachi, Japan) operated at $7 \mathrm{kV}$ and UHR-LVSEM (S-900LV, Hitachi, Hitachi, Japan) operated at $2 \mathrm{kV}$. Additionally, after prefixing with GA, mPL and spherules were treated with Updegraff reagent (Updegraff 1969) for $1 \mathrm{~h}$ at $80^{\circ} \mathrm{C}$. They were also observed by SEM in accordance with the standard protocols mentioned above.

In vivo labeling

As described previously (Ogawa et al. 2010), mPL were cultured for $72 \mathrm{~h}$ in $50 \mathrm{ml}$ of 1 or $2 \%$ medium containing $50 \mu \mathrm{l}$ of $1.7 \mathrm{mM} \mathrm{D}-\left[\mathrm{U}_{-}{ }^{14} \mathrm{C}\right]$ glucose (specific activity, $11.06 \mathrm{GBq} / \mathrm{mmol}$; GE Healthcare). Every $24 \mathrm{~h}$ during the $72 \mathrm{~h}$ culture, mPL were harvested by centrifugation, and the cell wall fraction was prepared as described in the section of "Isolation of native cellulose microfibrils." The amount of $\mathrm{D}-\left[\mathrm{U}-{ }^{14} \mathrm{C}\right]$ glucose incorporated in the cell wall fraction was measured in a liquid scintillation mixture, using a multipurpose scintillation counter LS6500 (Beckman, CA, USA). Moreover, after $72 \mathrm{~h}$ of culture, the cell wall fraction was treated with Updegraff reagent for $1 \mathrm{~h}$ at $80^{\circ} \mathrm{C}$, and the amount of D-[U- $\left.{ }^{14} \mathrm{C}\right]$ glucose incorporated in the soluble and insoluble fractions was measured as described above.

\section{Results}

Effect of DCB on mPL during preculture

To confirm cellulose deposition in step 2, we performed the following experiment. mPL from steps 1 and 2 were treated with $\mathrm{CBD}$ and immunostained with the primary monoclonal anti-CBD antibody produced in a mouse and then with the secondary goat anti-mouse IgG antibody conjugated to Alexa Fluor 568. As shown in Fig. 1, fluorescence microscopy showed that the cytoplasms of $\mathrm{mPL}$ maintained their tubelike structure at $84 \mathrm{~h}$ in step 1 after subculture (Fig. 1a), and an extremely faint fluorescence was observed from mPL subcultured for 84 at $0 \mathrm{~h}$ of step 2 (Fig. 1b). The cytoplasms assembled at the center of mPL (Fig. 1c) after the preculture for $72 \mathrm{~h}$ in 
Fig. 1 Effects of $100 \mu \mathrm{M}$ DCB added to medium in steps 1 and 2 on appearance and dry weight of mPL. Images a, $\mathbf{b}$ show the appearance of $\mathrm{mPL}$ cultured in the absence of DCB in step 1 . Images $\mathbf{c}, \mathbf{d}$ show the appearance of $\mathrm{mPL}$ cultured in the absence of DCB in step 2. Images $\mathbf{e}, \mathbf{f}$ show that in the presence of DCB in step 2. Bright field images, a, c, e. Fluorescence images, b, d, f. $\mathbf{g}$ The straight line indicates the dry weight of $\mathrm{mPL}$ cultured in the absence of DCB, and the dotted line indicates that in the presence of DCB in step 1. $\mathbf{h}$ The straight line indicates the dry weight of $\mathrm{mPL}$ cultured in the absence of DCB, and the dotted line indicates that in the presence of DCB in step 2. Scale bars, $100 \mu \mathrm{m}$
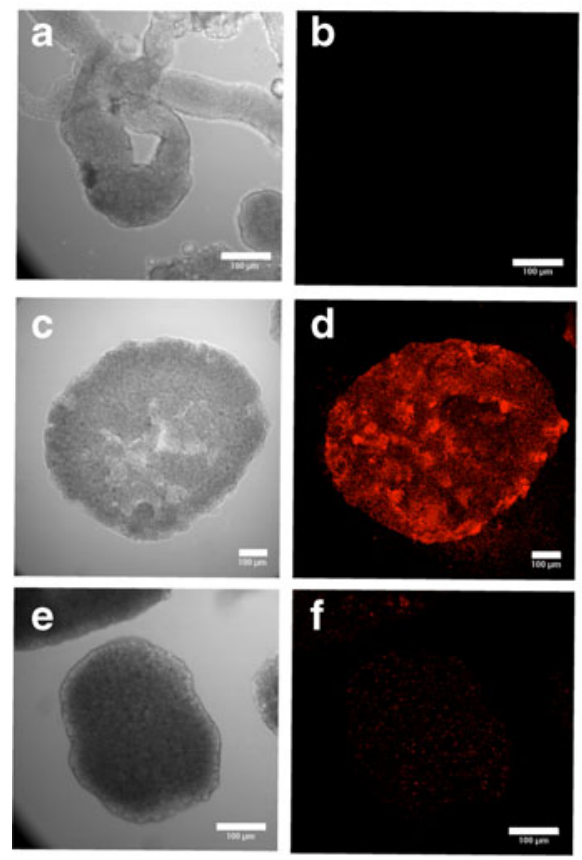
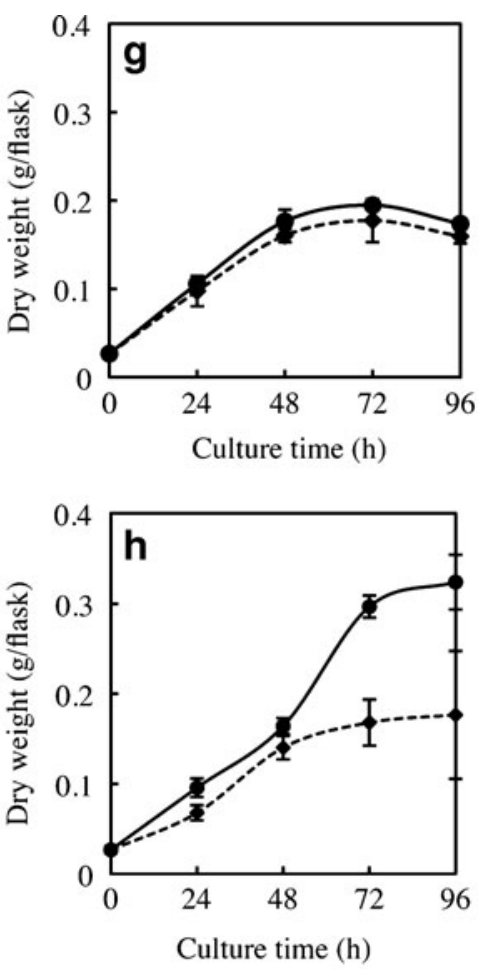

step 2. In contrast, cellulosic components of mPL cultured for $72 \mathrm{~h}$ in step 2 were deposited on the surface of mPL (Fig. 1d). However, when mPL were cultured in the presence of $100 \mu \mathrm{M}$ DCB in step 2 (Fig. 1e), these cytoplasms assembled more densely than those cultured without DCB in step 2 (Fig. 1c) and small amounts of deposited cellulosic components were detected (Fig. 1f). The two curves showing the changes in the dry weight of $\mathrm{mPL}$ cultured in the absence and presence of DCB in step 1 for $96 \mathrm{~h}$ were similar (Fig. $1 \mathrm{~g}$ ). As shown in Fig. 1h, the growth curve showing the changes in the dry weight of $\mathrm{mPL}$ cultured in the absence of DCB in step 2 for $96 \mathrm{~h}$ was quite different from the growth curve in the presence of DCB. The dry weight of $\mathrm{mPL}$ increased twofold from 48 to $72 \mathrm{~h}$ in the absence of DCB, compared with that of $\mathrm{mPL}$ in the presence of $\mathrm{DCB}$, which remained the same after $48 \mathrm{~h}$.

\section{$\mathrm{mPL}$ treated with Updegraff reagent}

To examine the structure of the surface of mPL cultured for $72 \mathrm{~h}$ in step 2, mPL were observed by SEM, which revealed that the surface of mPL was densely covered with netlike fibrils (Fig. 2a). However, after $\mathrm{mPL}$ were treated with Updegraff reagent for $1 \mathrm{~h}$ at $80{ }^{\circ} \mathrm{C}$ to sediment cellulose (Updegraff 1969), many scattered grains were observed on the surface of mPL as shown in Fig. 2b (arrows). Therefore, cellulase digestion of $\mathrm{mPL}$ was carried out following the treatment with Updegraff reagent. The density of scattered grains (Fig. 2b, arrows) apparently decreased on the surface of mPL, having been digested by cellulase (Fig. 2c).

\section{Isolation of cellulose fraction from $\mathrm{mPL}$}

For the observation of cellulose fibrils isolated from $\mathrm{mPL}, \mathrm{mPL}$ cultured in the $2 \%$ medium for $72 \mathrm{~h}$ in step 2 were directly treated with $1 \mathrm{~N} \mathrm{NaOH}$ and $0.3 \%$ $\mathrm{NaClO}_{2}$ sequentially, without the isolation of the cell wall fraction, because those cellulose fibrils were supposed to have not yet increased quantitatively to form the cell wall in mPL as in the case of spherules, as shown in Fig. 2b. The treated mPL were observed by SEM. As shown in Fig. 3a, a SEM image of the cellulose fibrils isolated from $\mathrm{mPL}$ showed many thin and long fibrils (Fig. 3a, arrows) entangled with the mPL debris. To confirm that the fibrils consisted of $\beta$-1,4-glucan, the cellulose fibrils isolated from mPL cultured for $72 \mathrm{~h}$ in step 2 were digested with cellulase. The fibrils (Fig. 3a) apparently decreased in amount following the cellulase digestion (Fig. 3b). On the other hand, the digestion by laminarinase did not change the appearance of the fibrils (Fig. 3c, arrows), as shown in the SEM images. Therefore, it was observed that at a low magnification, both the non-cellulase-digested mPL debris and laminarinase-digested mPL debris (Fig. 3d, f, respectively) were scarcely fragmented as compared with the cellulase-digested mPL debris (Fig. 3e), because the fibrils were entangled with the mPL debris. 
Fig. 2 Effect of cellulase digestion on $\mathrm{MPL}$ treated with Updegraff reagent. a SEM images show the appearance of cell surface of mPL in step 2, $\mathbf{b}$ after treatment with Updegraff reagent, and $\mathbf{c}$ after treatment with Updegraff reagent followed by digestion with cellulase. Arrows show scattered grains on cell surface of $\mathrm{mPL}$
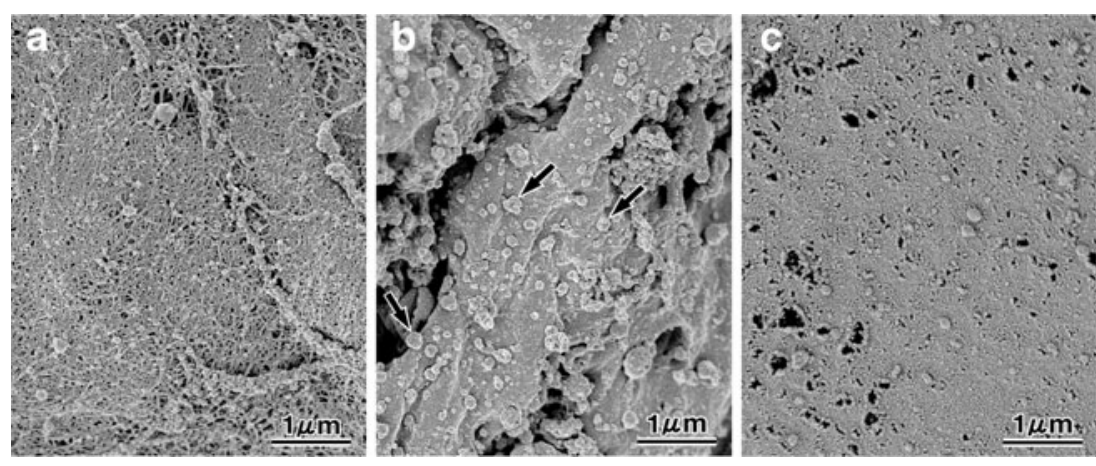

Spherules treated with Updegraff reagent and cellulose fraction isolated from spherules

To observe the appearance of cellulose fibrils in spherules, where the cellulose fibrils were formed up to the cell wall, the surface of spherules cultured for $96 \mathrm{~h}$ in step 3 was observed by SEM. To compare the sedimented cellulose in $\mathrm{mPL}$ shown in Fig. $2 \mathrm{~b}$ with that in spherules cultured for $96 \mathrm{~h}$ in step 3, spherules were treated with Updegraff reagent to sediment cellulose. The surface of spherules (Fig. 4a) was covered with the netlike fibrils of cellulose more densely than that of spherules not treated with Updegraff reagent (Ogawa et al. 2010), as shown previously. Moreover, it differed remarkably from the surface of mPL, which contained many scattered grains of cellulose (Fig. 2b). To observe more highly purified cellulose fibrils in spherules, the cell wall fraction was isolated from spherules cultured for $96 \mathrm{~h}$ in step 3 and was treated with $1 \mathrm{~N}$ $\mathrm{NaOH}$ and then in $0.3 \%(w / v) \mathrm{NaClO}_{2}$ for bleaching. We observed a firm structure consisting of a fine network of fibrils (Fig. 4b) rather than a netlike network of fibrils, as shown in Fig. 4a.
In vivo cellulose synthase activity

Cellulose fibrils were detected in mPL, as shown in Fig. 3; therefore, we isolated the cell wall fraction from mPL and examined the incorporation of $\mathrm{D}-\left[\mathrm{U}-{ }^{14} \mathrm{C}\right]$ glucose into the cell wall fraction. mPL were cultured in $2 \%$ medium containing D-[U- $\left.-{ }^{14} \mathrm{C}\right]$ glucose for $72 \mathrm{~h}$ in step 2, and then the amount of $\mathrm{D}-\left[\mathrm{U}_{-}{ }^{14} \mathrm{C}\right]$ glucose incorporated into the cell wall fraction from mPL was measured every $24 \mathrm{~h}$. As shown in Fig. 5a (straight line), the amount of $\mathrm{D}-\left[\mathrm{U}-{ }^{14} \mathrm{C}\right]$ glucose incorporated into the cell wall fraction from $\mathrm{mPL}$ cultured in the $2 \%$ medium increased exponentially with time for $72 \mathrm{~h}$. Then, after $\mathrm{mPL}$ were cultured in $1 \%$ medium containing $\mathrm{D}-\left[\mathrm{U}-{ }^{14} \mathrm{C}\right]$ glucose for $72 \mathrm{~h}$ in step 1 , the amount of $\mathrm{D}-\left[\mathrm{U}-{ }^{14} \mathrm{C}\right] \mathrm{glucose}$ incorporated into the cell wall fraction from mPL was measured every $24 \mathrm{~h}$. As shown in Fig. 5a (dotted line), the incorporation of D-[ $\left[\mathrm{U}^{14}{ }^{14} \mathrm{C}\right]$ glucose into the cell wall fraction increased linearly from 0 to $48 \mathrm{~h}$; however, $\mathrm{D}-\left[\mathrm{U}-{ }^{14} \mathrm{C}\right]$ glucose in $1 \%$ medium was not incorporated further into the cell wall fraction after $48 \mathrm{~h}$. The results in Fig. $5 \mathrm{a}$ are shown in Fig. $5 \mathrm{~b}$ on the basis of the increase in the amount of $\mathrm{D}_{-}\left[\mathrm{U}_{-}{ }^{14} \mathrm{C}\right] \mathrm{glucose}$ incorporated into the cell
Fig. 3 Effects of cellulase and laminarinase digestions on cellulose fraction isolated from $\mathrm{mPL}$ in step 2. a SEM images show the appearance of cellulose fraction isolated from $\mathrm{mPL}$ in step 2 and $\mathbf{d}$ its low magnification, $\mathbf{b}$ the appearance of cellulose fraction isolated from $\mathrm{mPL}$ in step 2 and then digested with cellulase and $\mathbf{e}$ its low magnification, and $\mathbf{c}$ the appearance of cellulose fraction isolated from $\mathrm{mPL}$ in step 2 and then digested with laminarinase and $\mathbf{f}$ its low magnification. Arrows show the cellulose fibrils isolated from $\mathrm{mPL}$
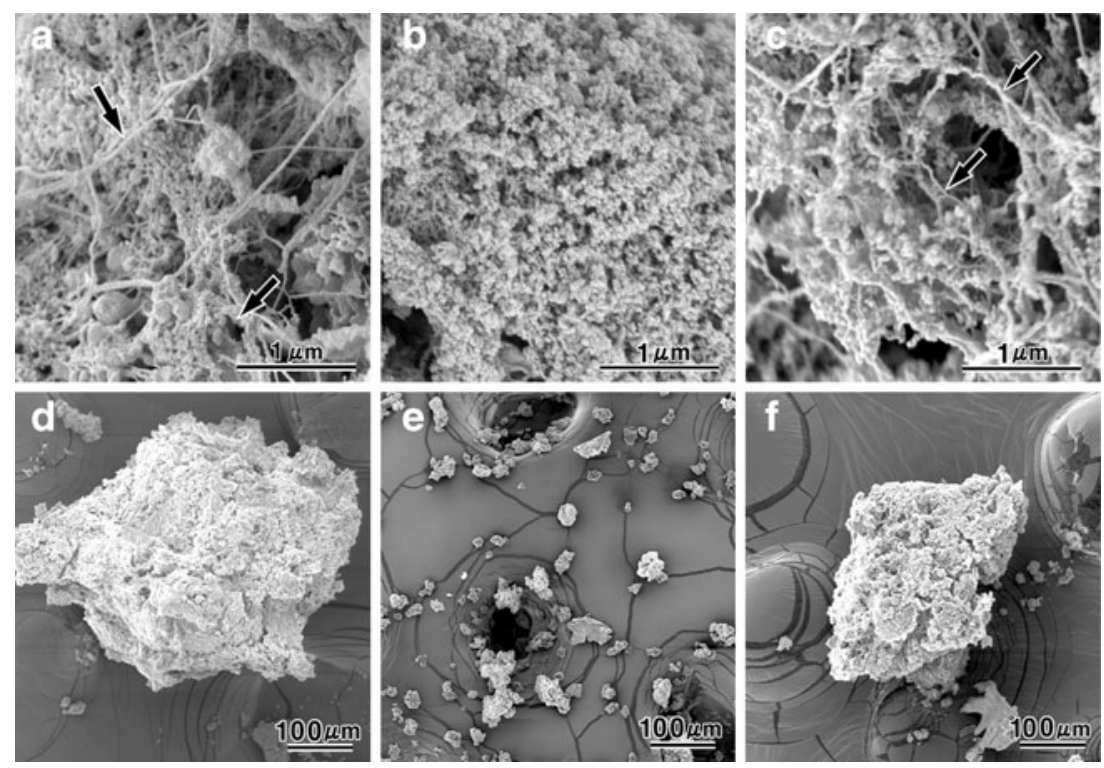
Fig. 4 Appearances of surface of spherules treated with Updegraff reagent and of cellulose isolated from cell wall fraction of spherules in step 3. a A spherule was treated with Updegraff reagent, and $\mathbf{b}$ the cell wall fraction of spherules was treated with $1 \mathrm{~N} \mathrm{NaOH}$ and then with $0.3 \%(w / v) \mathrm{NaClO}_{2}$
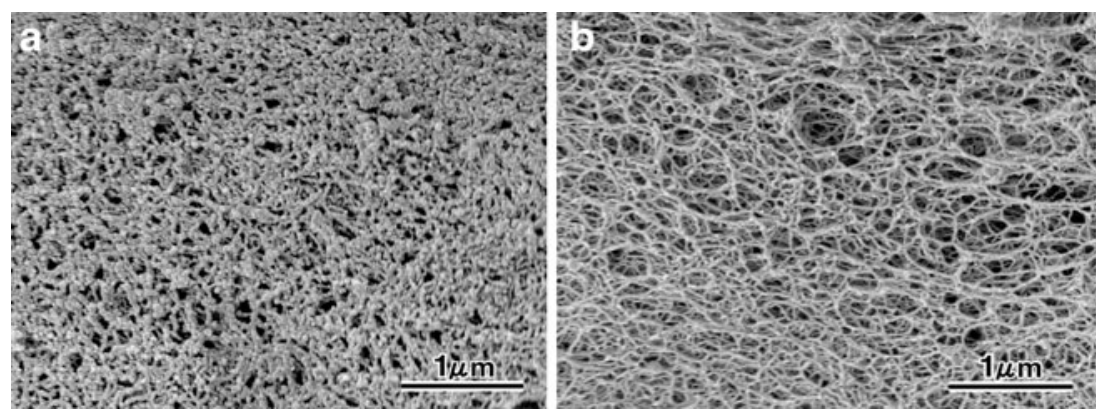

wall fraction at intervals of $24 \mathrm{~h}$. As shown in Fig. 5b, the amount of D-[U- $\left.{ }^{14} \mathrm{C}\right]$ glucose incorporated from 0 to $24 \mathrm{~h}$ and from 24 to $48 \mathrm{~h}$ showed almost the same extents of increase in mPL cultured in 1 and $2 \%$ media; however, the extents of the increase in the amount of incorporated of $\mathrm{D}-\left[\mathrm{U}-{ }^{14} \mathrm{C}\right]$ glucose from 48 to $72 \mathrm{~h}$ into the cell wall fraction from mPL cultured in $1 \%$ medium decreased by one fifth of that from 24 to $48 \mathrm{~h}$ (Fig. 5b, white bars). In contrast, it was found that the amount of $\mathrm{D}-\left[\mathrm{U}_{-}{ }^{14} \mathrm{C}\right]$ glucose incorporated from 48 to $72 \mathrm{~h}$ into the cell wall fraction from $\mathrm{mPL}$ cultured in $2 \%$ medium increased approximately by more than twofold than that from 24 to $48 \mathrm{~h}$ (Fig. 5b, gray bars) and therefore reached more than eightfold than that incorporated into the cell wall fraction from mPL cultured in $1 \%$ medium. It was supposed that the increase in the amount of $\mathrm{D}-\left[\mathrm{U}-{ }^{14} \mathrm{C}\right]$ glucose incorporated for $72 \mathrm{~h}$ into $\mathrm{mPL}$ was caused by the increase in the thickness of the cell wall; therefore, the dry weight of mPL cultured in 1 or $2 \%$ media was measured every $24 \mathrm{~h}$. The dry weight of mPL cultured in $2 \%$ medium increased exponentially with time for $72 \mathrm{~h}$ (Fig. 5c, straight line); however, that of mPL cultured in $1 \%$ medium did not increase after $48 \mathrm{~h}$ (Fig. 5c, dotted line). It was revealed that these two growth curves (Fig. 5c) are linked with the changes in the amount of $\mathrm{D}-\left[\mathrm{U}-{ }^{14} \mathrm{C}\right]$ glucose incorporated into the cell wall fraction from mPL cultured in 1 and $2 \%$ media, as shown in Fig. 5a. Moreover, the results in Fig. 5c are shown in Fig. $5 \mathrm{~d}$ on the basis of the increase in dry weight at intervals of $24 \mathrm{~h}$. As shown in Fig. 5d, the dry weight from 0 to $24 \mathrm{~h}$ and from 24 to $48 \mathrm{~h}$ remained almost the same in mPL cultured in 1 and $2 \%$ media; however, the dry weight from 48 to $72 \mathrm{~h}$ in mPL cultured in $1 \%$ medium decreased by one
Fig. 5 Comparison of metabolically labeled cell wall fraction between $\mathrm{mPL}$ growing in $1 \%$ and that in $2 \%$ medium. a The figure indicates the amounts of incorporated D$\left[{ }^{14} \mathrm{C}\right]$ glucose in $1 \%$ medium (dotted line) and $2 \%$ medium (straight line). b The figure indicates the increases in the amount of incorporated of D$\left[{ }^{14} \mathrm{C}\right]$ glucose every $24 \mathrm{~h}$ in $1 \%$ medium (white bars) and $2 \%$ medium (gray bars). $\mathbf{c}$ The figure indicates the dry weights of $\mathrm{mPL}$ in $1 \%$ medium (dotted line) and $2 \%$ medium (straight line). $\mathbf{d}$ The figure indicates the increases in dry weight every $24 \mathrm{~h}$ in $1 \%$ medium (white bars) and $2 \%$ medium (gray bars)
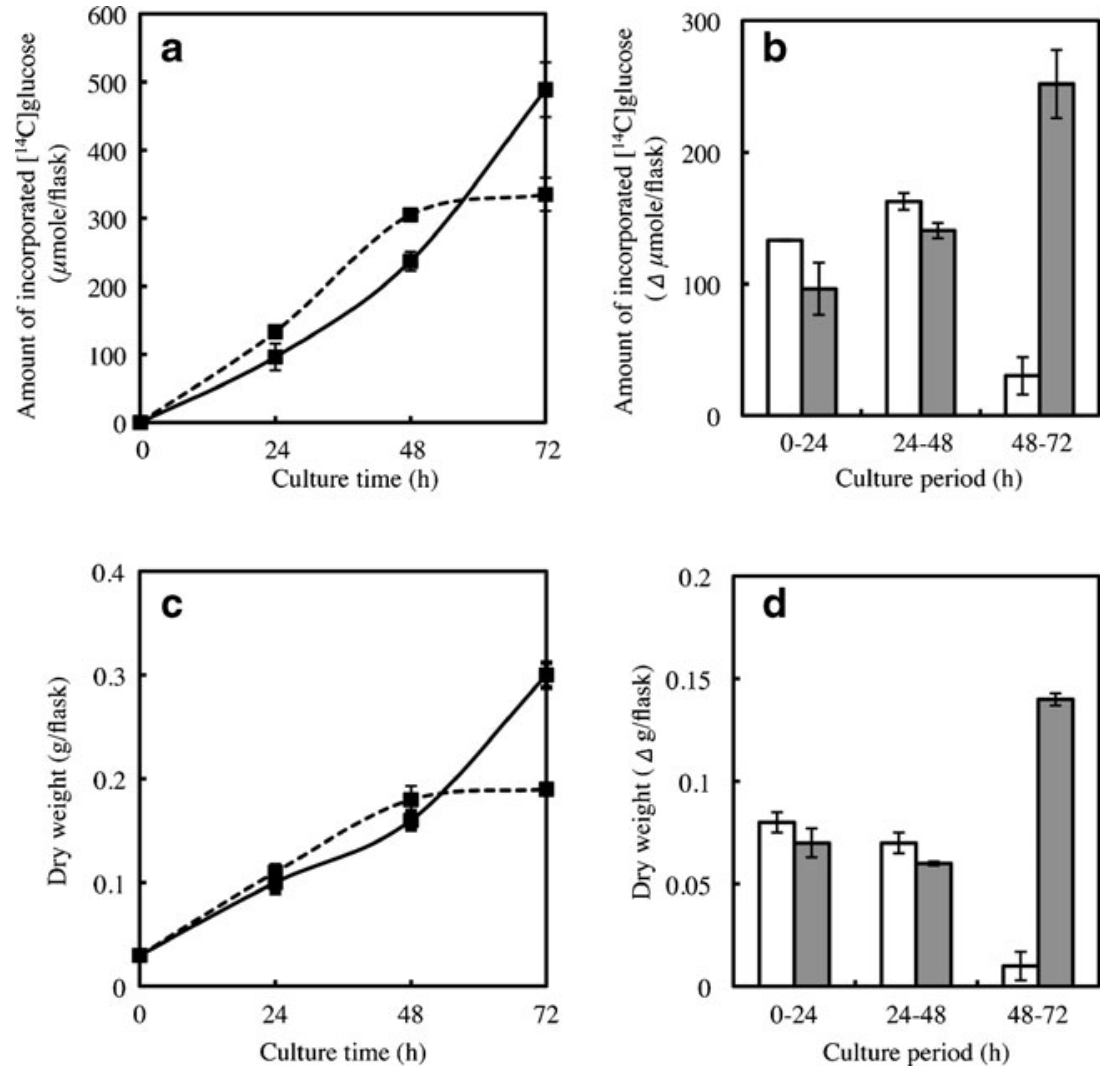
seventh of that from 24 to $48 \mathrm{~h}$ (Fig. 5 d, white bars). In contrast, it was revealed that the dry weight from 48 to $72 \mathrm{~h}$ for mPL cultured in $2 \%$ medium increased approximately by more than twofold than that from 24 to 48 h (Fig. 5d, gray bars) and reached more than tenfold than that of $\mathrm{mPL}$ cultured in $1 \%$ medium, the extent of increase of which declined by one fifth of those from 0 to 24 and from 24 to $48 \mathrm{~h}$. Similar tendencies were also observed for the changes in the amount of incorporated D-[U- $\left.{ }^{14} \mathrm{C}\right]$ glucose into the cell wall fraction (Fig. 5a) and in dry weight (Fig. 5c), and also for the net increases in the amount of incorporation every $24 \mathrm{~h}$ (Fig. 5b) and dry weight every 24 h (Fig. 5d).

Moreover, according to the definition by Peng and coworkers $(2001,2002)$, glucan remaining insoluble after treatment with Updegraff reagent is crystalline cellulose, and 4-linked glucan not resistant to the reagent is noncrystalline cellulose. In this experiment, to determine the amount of D- $\left[\mathrm{U}_{-}{ }^{14} \mathrm{C}\right] \mathrm{glucose}$ incorporated into the insoluble fraction from the cell wall fraction, the cell wall fractions of mPL cultured in 1 and $2 \%$ media containing D- $\left[\mathrm{U}-{ }^{14} \mathrm{C}\right]$ glucose after $72 \mathrm{~h}$ were treated with Updegraff reagent. As shown in Table 1, the amounts of $\mathrm{D}-\left[\mathrm{U}-{ }^{14} \mathrm{C}\right]$ glucose incorporated into the insoluble fraction from the cell wall fraction in either 1 or $2 \%$ media were merely $5-6 \%$ of the total amount of incorporated D-[U- $\left.-{ }^{14} \mathrm{C}\right]$ glucose.

\section{Discussion}

First, we found that the major component of the cell wall of spherules in P. polycephalum was cellulose. Second, we also elucidated by in vivo labeling experiment in the presence of DCB that it was in the nourishment medium in step 2 prior to the dark-starvation treatment that $\mathrm{mPL}$ of multinucleated protoplasts synthesized cellulose fibrils, as observed in our previous study (Ogawa et al. 2010). To obtain supporting evidence for the second finding, we carried out two sets of experiments to examine the effect of DCB on the synthesis

Table 1 Effect of Updegraff reagent treatment on cell wall fraction of $\mathrm{mPL}$

\begin{tabular}{lcc}
\hline & \multicolumn{2}{c}{ Amount of incorporated D- $\left[{ }^{14} \mathrm{C}\right]$ glucose $(\%)$} \\
\cline { 2 - 3 } & $2 \%$ medium & $1 \%$ medium \\
\hline Total & 100 & 100 \\
Insoluble fraction & $6.25 \pm 1.97$ & $5.77 \pm 1.50$ \\
Soluble fraction & $93.75 \pm 1.97$ & $94.23 \pm 1.50$ \\
\hline
\end{tabular}

$\mathrm{mPL}$ were cultured in 1 and $2 \%$ media containing $50 \mu \mathrm{l}$ of $1.7 \mathrm{mM}$ D$\left[\mathrm{U}-{ }^{14} \mathrm{C}\right]$ glucose (specific activity, $11.06 \mathrm{GBq} / \mathrm{mmol}$ ). After $72 \mathrm{~h}$, the cell wall fractions were extracted from $\mathrm{mPL}$ and treated with Updegraff reagent. The amount of $\mathrm{D}-\left[\mathrm{U}_{-}-{ }^{14} \mathrm{C}\right]$ glucose incorporated into the soluble or insoluble fraction was measured using a scintillation counter of cellulose in mPL by the immunostaining method and by measuring the dry weight of $\mathrm{mPL}$ during culture. $\mathrm{mPL}$ cultured in $1 \%$ medium in step 1 showed an extremely faint fluorescence, as determined by fluorescence microscopy (Fig. 1a, b), and the dry weight of mPL was not affected by the addition of DCB (Fig. 1g). However, as shown clearly in Fig. 1c, d, mPL cultured in $2 \%$ medium in step 2 show cellulose deposited on their surface with mPL assembling together at the center. Because the assembly of mPL is a necessary step in the formation of spherules (compare Fig. 1c with Fig. 1a), it was found that despite the denser assembly of mPL in Fig. 1e than in Fig. 1c, the presence of DCB in step 2 caused the cessation of both cellulose synthesis in $\mathrm{mPL}$, as shown in Fig. 1f, and increase in dry weight at the interval from 48 to $72 \mathrm{~h}$ (Fig. 1h, dotted line). It was confirmed definitely that mPL, on which the cell wall was not formed, synthesized cellulose in the preculture period. The twofold increase in the dry weight of $\mathrm{mPL}$ from 48 to $72 \mathrm{~h}$ (Fig. 1h, straight line) in step 2 in the absence of DCB compared with the increase in the presence of DCB (Fig. 1h, dotted line) may be explained by the deposition of cellulose, as shown by fluorescence microscopy (Fig. 1d).

To elucidate the structure of cellulose synthesized by mPL, the cell surface of mPL was first observed by SEM. Kimura and Itoh (1998) treated bodies of P. misakiensis with Updegraff reagent to remove noncellulosic substances (Updegraff 1969) and visualized a specialized structure, that is, the tunic cord, under a transmission electron microscope and a scanning electron microscope. They reported that the tunic cords are composed of bundled microfibrils of cellulose I with high crystallinity, and a tunic cord is completely surrounded by single-layered epidermal cells. Therefore, to visualize the structure of purified cellulose in mPL by SEM, we used Updegraff reagent to sediment cellulose (Fig. 2). It is supposed that the netlike fibrils (Fig. 2a) covering the surface of $\mathrm{mPL}$ that disappeared following the treatment with Updegraff reagent were noncellulosic components. After the treatment with the reagent, many scattered grains appeared under the netlike fibrils on the surface of mPL (Fig. 2b, arrows). Considering the digestion of these grains by cellulase (Fig. 2c), it was likely that they were composed of cellulose. This suggests that cellulose is localized outside of mPL.

On the other hand, it is supposed that using the cellulose fibrils synthesized, Physarum mPL form the structure of the cell wall of spherules during the dark-starvation treatment for spherulation. After the spherules cultured for $96 \mathrm{~h}$ in step 3 were treated with Updegraff reagent, they were shown by SEM to be covered with the netlike network of fibrils (Fig. 4a). Moreover, the cell wall fraction from spherules purified with $\mathrm{NaOH}$ and $\mathrm{NaClO}_{2}$ showed that the firm structure consisted of a fine network of fibrils (Fig. 4b) rather than a netlike network of fibrils, which was observed in the spherules treated with Updegraff reagent (Fig. 4a). In 
this study, to elucidate the formation of the cell wall from mPL (Fig. 2) to spherules (Fig. 4), we isolated cellulose fibrils from mPL. As shown in Fig. 3a, it was likely that the visualized cellulose fibrils were composed of many thin long fibrils that became entangled with mPL debris, because the fibrils were removed not by laminarinase (end-1,3- $\beta$ glucanase) digestion but by cellulase (end-1,4- $\beta$-glucanase) digestion (Fig. 3b, c). We still do not know precisely the components of the netlike fibrils on the surface of mPL, as shown in Fig. 2a. Kimura et al. (1999) described that the intact rosette terminal complex of the cellulose synthesis machinery is present with its major subunits embedded preferentially in the inner leaflet of the plasma membrane and the catalytic subunit exposed to the cytoplasm. Nascent glucan chains originating from the catalytic subunit site originate from the globular domain, which is predicted to lie in the cytoplasmic volume. Peng et al. (2002) defined that crystalline cellulose is glucan remaining insoluble after treatment with Updegraff reagent and that noncrystalline cellulose is 4-linked glucan, which is not resistant to Updegraff reagent. Taking these reports (Kimura et al. 1999; Peng et al. 2002) and our finding on the effect of Updegraff reagent on $\mathrm{mPL}$ (Fig. 2) into consideration, that is, cellulose was not necessary for mPL in step 2 without the cell wall structure to construct the cell wall, we illustrate that nascent glucan chains synthesized in mPL are likely not crystalline cellulose after they are released to the cell surface and that they accumulate on the surface of the plasma membrane of mPL.

To confirm this presumption, we conducted an in vivo labeling experiment using $\mathrm{D}-\left[\mathrm{U}-{ }^{14} \mathrm{C}\right]$ glucose and measured the amount of $\mathrm{D}_{-}\left[\mathrm{U}_{-}{ }^{14} \mathrm{C}\right]$ glucose incorporated into the cell wall fraction from mPL. As shown in Fig. 5b, the amount of $\mathrm{D}-\left[\mathrm{U}-{ }^{14} \mathrm{C}\right]$ glucose incorporated from 48 to $72 \mathrm{~h}$ into $\mathrm{mPL}$ cultured in $2 \%$ medium showed an approximately twofold increase from 24 to $48 \mathrm{~h}$ (gray bars) and, at the same time, reached a more than eightfold increase as compared with that into $\mathrm{mPL}$ cultured in $1 \%$ medium (white bars). The finding of our previous study (Ogawa et al. 2010) that the synthesis of the cellulosic component from the supplied $\mathrm{D}-\left[\mathrm{U}-{ }^{14} \mathrm{C}\right]$ glucose is inhibited by DCB in mPL is supported by the finding that the incorporation of $\mathrm{D}-\left[\mathrm{U}_{-}{ }^{14} \mathrm{C}\right]$ glucose (Fig. 5a, b) is concomitant with the changes in dry weight (Fig. 5c, d); we concluded that the incorporation of $\mathrm{D}-\left[\mathrm{U}-{ }^{14} \mathrm{C}\right]$ glucose reflects cellulose synthesis in $\mathrm{MPL}$ and that cellulose is produced by de novo synthesis. Furthermore, the fact that the amount of D- $\left[\mathrm{U}_{-}{ }^{14} \mathrm{C}\right]$ glucose incorporated for $24 \mathrm{~h}$ into mPL cultured in $2 \%$ medium (Fig. 5 b, gray bars) increased markedly from 48 to $72 \mathrm{~h}$ as compared with that into $\mathrm{mPL}$ cultured in $1 \%$ medium (Fig. $5 \mathrm{~b}$, white bars) revealed that high-nourishment medium condition caused the induction of the abundant accumulation of cellulose by the activated cellulose synthesis. Taking our result into consideration that cellulose synthesis was repressed after $48 \mathrm{~h}$ in
$1 \%$ medium but that it was activated remarkably at $48 \mathrm{~h}$ in $2 \%$ medium (Fig. 5a, b), we found the exact conversion point at $48 \mathrm{~h}$ in step 2 of our system.

Next, the cell wall fractions from mPL cultured in 1 and $2 \%$ media containing D-[U- $\left.{ }^{14} \mathrm{C}\right]$ glucose for $72 \mathrm{~h}$ were treated with Updegraff reagent. As shown in Table 1, the amounts of incorporated D-[U- $\left.{ }^{14} \mathrm{C}\right]$ glucose of the insoluble fraction with respect to the total amount incorporated, which was resistant to treatment with the reagent, were merely 5$6 \%$ both in mPL cultured in 1 and $2 \%$ media. On the other hand, the amounts of incorporated $\mathrm{D}-\left[\mathrm{U}-{ }^{14} \mathrm{C}\right]$ glucose of the soluble fraction with respect to the total amount incorporated, which was not resistant to treatment with the reagent, were $93-94 \%$ both in mPL cultured in 1 and $2 \%$ media. Because the cell wall fraction from mPL consists mostly of cellulose not resistant to treatment with the reagent, we propose that cellulose produced in $\mathrm{mPL}$ is most likely noncrystalline cellulose regardless of the nourishment medium condition. According to the definition of Peng et al. (2002), this proposal leads us to the conclusion that, as shown in Fig. 2, the majority of netlike fibrils covering the surface of mPL (Fig. 2a) are noncrystalline cellulose, and many scattered grains that appeared under the netlike fibrils on the surface of mPL (Fig. $2 b$ ) are crystalline cellulose. The noncrystalline cellulose in $\mathrm{mPL}$ is formed in the cell wall of spherules during the starvation treatment within $48 \mathrm{~h}$ after induction, forming an interwoven, regular, meshlike, strong structure (Fig. 4b). Therefore, in agreement with our presumption, it is likely that mPL of multinucleated protoplasts, without the cell wall structure, synthesize cellulose under constitutive conditions and accumulate abundant amounts of noncrystalline cellulose, in preparation for unfavorable environments in which $\mathrm{mPL}$ must initiate the program leading to the formation of the cell wall of spherules in the future. It can be called the biased glucan synthesis that mPL of protoplasts accumulate constitutively abundant amounts of noncrystalline cellulose. When plant cell wall is wounded by mechanical stress, plant cell temporarily synthesizes $\beta$ 1,3 -glucan (callose), though it usually synthesizes $\beta-1,4$ glucan (cellulose) for plant cell wall. The case is one of the biased glucan syntheses which would benefit plant defense mechanism. In regeneration of cellulose by plant protoplasts, noncrystalline cellulose synthesized at the first stage is supposed to change into crystalline cellulose on the same surface of the protoplasts continuously. However, Physarum mPL of protoplasts constitutively synthesize noncrystalline cellulose, whether the protoplasts are transferred in the stress conditions or not. Therefore, Physarum mPL are good system to provide insoluble noncrystalline cellulose, which can be a potential application in the near future.

In this study, we aimed to clarify the accumulation of the cellulose fibrils of the cell wall fraction in Physarum mPL and to determine when cellulose synthesis is activated 
within a period of $72 \mathrm{~h}$ in step 2 . We found that the fibrils isolated from $\mathrm{mPL}$ were composed of cellulose and that the conversion starts at $48 \mathrm{~h}$ in step 2 of our system. From the results of the experiments using Updegraff reagent for the treatment of the cell wall fraction from $\mathrm{mPL}$, we propose that cellulose produced in mPL is likely noncrystalline cellulose, which is synthesized without any induction and is accumulated abundantly. In conclusion, as compared with noncrystalline cellulose, crystalline cellulose rather hinders Physarum mPL from crawling around to look for food, causing rapid cytoplasmic streaming. However, it is necessary for Physarum mPL to synthesize noncrystalline cellulose for the formation of their cell wall necessary for their survival when encountering unfavorable environments.

Acknowledgments We thank Dr. R. Kaida (Tokyo University of Agriculture) for the helpful advice and useful discussion during this research. We appreciate the assistance of Ms. Y. Yamada (Japan Women's University) and the expertise of Ms. H. Kato (Leica Microsystems K. K.) in fluorescence microscopy using a confocal laser scanning head.

Conflict of interest The authors declare that they have no conflict of interest.

Open Access This article is distributed under the terms of the Creative Commons Attribution License which permits any use, distribution, and reproduction in any medium, provided the original author(s) and the source are credited.

\section{References}

Arioli T, Peng L, Betzner AS, Burn J, Wittke W, Herth W, Camilleri C, Höfte H, Plazinski J, Birch R, Cork A, Glover J, Redmond J, Williamson RE (1998) Molecular analysis of cellulose biosynthesis in Arabidopsis. Science 279:717-720
Cifuentes C, Bulone V, Emons AMC (2010) Biosynthesis of callose and cellulose by detergent extracts of tobacco cell membranes and quantification of the polymers synthesized in vitro. J Integr Plant Biol 52:221-233

Crasnier M, Giordani R (1985) Elution of acid phosphatase from sycamore cell walls. Plant Sci 40:35-41

Guttes E, Guttes S (1963) Starvation and cell wall formation in the myxomycete Physarum polycephalum. Ann Bot N S 27:49-53

Kimura S, Itoh T (1998) A new cellulosic structure, the tunic cord in the ascidian Polyandrocarpa misakiensis. Protoplasma 204:94102

Kimura S, Laosinchai W, Itoh T, Cui X, Linder CR, Brown RM (1999) Immunogold labeling of rosette terminal cellulose-synthesizing complexes in the vascular plant Vigna angularis. Plant Cell 11:2075-2085

Lai-Kee-Him J, Chanzy H, Müller M, Putaux J-L, Imai T, Bulone V (2002) In vitro versus in vivo cellulose microfibrils from plant primary wall synthases: structural differences. J Biol Chem 277:36931-36939

Ogawa K, Sato M, Ashihara H, Kaneko TS (2010) Evidence for deposition of cellulose prior to dark-starvation treatment during spherulation in Physarum microplasmodia. Cytologia 75:397-407

Peng L, Xiang F, Roberts E, Kawagoe Y, Greve LC, Kreuz K, Delmer DP (2001) The experimental herbicide CGA 325'615 inhibits synthesis of crystalline cellulose and causes accumulation of non-crystalline $\beta$-1,4-glucan associated with CesA protein. Plant Physiol 126:981-992

Peng L, Kawagoe Y, Hogan P, Delmer D (2002) Sitosterol- $\beta$ glucoside as primer for cellulose synthesis in plants. Science 295:147-150

Scott TA, Melvin EH (1953) Determination of dextran with anthrone. Anal Chem 25:1656-1661

Takahashi J, Rudsander UJ, Hedenström M, Banasiak A, Harholt J, Amelot N, Immerzeel P, Ryden P, Endo S, Ibatullin FM, Brumer H, Campillo E, Master ER, Scheller HV, Sundberg B, Teeri TT (2009) KORRIGAN1 and its aspen homolog PttCel9A1 decrease cellulose crystallinity in Arabidopsis stems. Plant Cell Physiol 50:1099-1115

Updegraff DM (1969) Semimicro determination of cellulose in biological materials. Anal Biochem 32:420-424 